\title{
Earnings management and cross listing: Are reconciled earnings comparable to US earnings?ח
}

\author{
Mark Lang $^{\mathrm{a}, *}$, Jana Smith Raedy ${ }^{\mathrm{a}}$, Wendy Wilson ${ }^{\mathrm{b}}$ \\ ${ }^{a}$ Kenan-Flager Business School, University of North Carolina, Chapel Hill, Chapel Hill, \\ NC 27599-3490, USA \\ ${ }^{b}$ Cox School of Business, Southern Methodist University, Dallas, TX 75275-0333, USA
}

Received 1 March 2004; received in revised form 26 September 2005; accepted 4

October 2005

\begin{abstract}
We compare US firms' earnings with reconciled earnings for cross listed non-US firms. Non-US firms' earnings exhibit more evidence of smoothing, greater tendency to manage towards a target, lower association with share price and less timely recognition of losses. Firms from countries with weaker investor protection show more evidence of earnings management, suggesting that SEC regulation does not supplant the effect of local environment. There is more evidence of earnings management for firms reconciling to US GAAP than for those preparing local accounts in accordance with US GAAP, but both show more evidence of earnings management than US firms.
\end{abstract}

JEL classification: G18; M41; M43; M44

Keywords: International accounting; Earnings management; Cross-listing

$\Pi W e$ thank Mark Bradshaw (the referee), Doug Skinner (the editor), Christian Leuz (the discussant), and participants at the 2004 Journal of Accounting and Economics conference and workshops at the University of Southern California, Duke University, University of Minnesota, London Business School and University of Oklahoma for helpful comments.

*Corresponding author. Tel.: +1 919-962-1644; fax: +1 919-962-4727.

E-mail address: mark_lang@unc.edu (M. Lang). 


\section{INTRODUCTION}

One feature that differentiates the US from other regulatory environments is its requirement that foreign firms wishing to cross list on US exchanges reconcile their net income and shareholders' equity to US GAAP. ${ }^{1}$ From the SEC's investor protection perspective, US investors should have access to information on cross-listed non-US firms trading on US exchanges that is comparable and of similar quality to that presented by US firms (Jenkins, 1999). While there is a substantial body of literature on cross listing in general and the value relevance of accounting reconciling items in particular, there is little evidence on the characteristics of the "US GAAP" accounting data that result from the reconciliation process.

In general, there appears to be an underlying presumption that cross-listing firms are held to similar standards as US-domiciled firms (Coffee, 2002). While the explicit requirements of Form 20-F hold foreign registrants to similar standards as domestic firms, a growing body of literature suggests that application of accounting standards depends crucially on factors like regulatory enforcement, legal environment and managerial incentives. To the extent that cross-listed firms face different incentives and regulatory enforcement, the characteristics of their reconciled accounting data may differ predictably from those reported by US firms. ${ }^{2}$

There are several factors that potentially affect cross-listing firms' reporting incentives differently from the incentives of US firms. One factor is the enforcement and litigation environment. As SEC registrants, cross-listing firms face the same basic de jure regulations as do US firms in that their filings are subject to the same SEC oversight. The SEC has broad authority to investigate securities law violations by cross-listed firms

\footnotetext{
${ }^{1}$ Form 20-F requires that a firm provide a reconciliation of "material variations in the accounting principles, practices, and methods used in preparing the financial statements from the principles, practices, and methods generally accepted in the United States and in Regulation S-X." (http://www.sec.gov/about/forms/form20-f.pdf). Our primary interest is in accounting data reconciled to US GAAP and, hence, we exclude Canadian firms and firms that trade on the OTC Bulletin Board market since they are not required to prepare reconciliations.

${ }^{2}$ We focus on the characteristics of reconciled accounting data, rather than the entire package of information provided on Form 20-F. Foreign registrants are, for example, exempted from some footnote and periodic filing requirements. While it would be interesting to assess whether the overall level of disclosure is comparable for cross-listed and US firms, we believe the issue of whether the accounting data provided in reconciliations are comparable is of interest to the SEC (Breeden, 1994) and is an important issue in its own right.
} 
and seek appropriate remedies, including injunctive actions in federal courts, administrative proceedings, and civil and criminal contempt proceedings (Frost and Pownall, 1994). Similarly, US investors in cross-listed firms have the same basic legal protections as investors in US-domiciled firms because these firms fall under the US securities laws and, hence, are subject to litigation in US courts.

However, as discussed in Siegel (2005) and Frost and Pownall (1994), the extent of regulatory and legal exposure can differ in practice even if many of the safeguards are nominally the same. ${ }^{3}$ Siegel (2005) argues that issues of jurisdiction and priorities reduce the willingness of the SEC to devote scarce resources to pursuing claims against non-US firms and that, in cases in which the SEC has done so, they typically were not successful. Similarly, shareholders litigating against cross-listed firms have difficulty gaining access to the necessary documents in the foreign jurisdiction and often end up settling for very little. Siegel (2005) conducts an exhaustive review of all SEC litigation from 1995-2002 against cross-listed firms and finds only thirteen cases that the SEC prosecuted, often unsuccessfully. Further, he examines in detail several cases of Mexican firms where, ex post, there was clear evidence of fraud and finds little evidence of SEC action in response to the fraud or of minority investor success in pursuing cases against the firms. He concludes,

"the SEC has rarely been able to enforce U.S. securities laws against any U.S.-listed foreign firm. Minority shareholders frequently attempt to use the U.S. courts to enforce the securities laws against cross-listed foreign firms. However, institutional obstacles also hinder minority shareholders, and they are often forced to accept token settlements. The insiders responsible for the governance abuses rarely are forced to pay any significant compensation to the shareholders. The public knowledge of this impunity further compounds the moral hazard problem."

Consistent with Siegel's findings, Frost and Pownall (1994) examine SEC disclosure enforcement and are unable to find any instances in which disclosure violations by foreign issuers have been tested in court or have been subject to formal investigation or administrative proceeding. In addition, they investigate the extent to

\footnotetext{
${ }^{3}$ See also La Porta et al. (2000) and Licht $(2000,2003)$ for discussions of the limitations of US enforcement and minority rights protection for cross-listed firms.
} 
which foreign issuers comply with explicit SEC filing requirements. They find substantial noncompliance with annual and interim reporting requirements, and with rules requiring foreign firms to disclose in the US information made public in the local environment.

Potentially exacerbating the effect of the enforcement and litigation environment is the possibility that managers of international firms face increased incentives to manage earnings. Although research evidence suggests that managers everywhere face incentives to smooth earnings and avoid losses, the incentives may be particularly strong in international contexts. As argued in Ball et al. (2000), for example, non-US firms often operate in stakeholder corporate governance environments where constituencies such as labor and banks are more commonly represented on corporate boards. Because those stakeholders typically do not share as much in the upside and face risk on the downside, they may create incentives for management to report earnings with lower variance. In the extreme, reporting high profits likely attracts political costs and greater demands from governments and labor, and large losses may increase the probability of intervention to ensure the viability of the firm. More generally, as argued in Leuz et al. (2003), smoothing creates opacity which may help firms avoid scrutiny from outsiders (including governments) and facilitate wealth expropriation by insiders. In discussions of relaxing cross-listing requirements, a consistent theme has been concern about earnings management by international firms (Breeden, 1994). ${ }^{4}$

If managers of cross-listed firms perceive that there are incentives to manage earnings and relatively lax oversight, it may affect the characteristics of the accounting data reported in the US market. ${ }^{5}$ Our analysis compares the characteristics of reconciled

\footnotetext{
${ }^{4}$ Ultimately, we cannot conclusively differentiate between the effects of incentives and the effects of regulation on earnings management since, as with other research in this area, the two are so closely linked. Non-US firms may well face a combination of increased pressure to manage earnings in the local market, relaxed oversight of the local accounts and reduced scrutiny by the SEC. Our primary goal is simply to document whether the characteristics of the resulting accounting data differ in predictable ways from those provided by US firms. We attempt to differentiate between explanations in the supplementary analysis by, for example, comparing firms across different home regulatory environments and different US filing requirements. However, the samples sizes are generally small and the design hurdles formidable in making strong causality statements.

${ }^{5}$ We do not mean to imply that managers are necessarily "unsavory" in their actions. They may simply face a different set of incentives to, for example, smooth earnings in the local market which they do not feel obligated to undo in their US-reported accounts because of a relaxed enforcement environment. Our
} 
accounting data for cross-listed firms with data reported by a matched sample of US firms, including controls for factors likely to affect the cross-listing decision. We focus on accounting characteristics that prior research like Leuz et al. (2003) and Lang et al. (2003b) suggests are potentially important to the informativeness of accounting data: earnings smoothing, tendency to manage earnings towards a target, timely loss recognition and general association with share price. We include a wide range of measures because of the inherent difficulty in measuring earnings management and to mitigate the potential effects of omitted variables that may affect some of our measures but are less likely to explain them all. Our research suggests that, relative to the US firms, cross-listed firms report reconciled earnings that are smoother compared to cash flows, show more of a tendency to use accruals to smooth cash flow volatility, report a higher proportion of small positive earnings, are less likely to recognize losses in a timely manner and generally report reconciled earnings and shareholders' equity data that are less highly correlated with share price, especially in cases of bad news. Consistent with predictions, the characteristics of reconciled accounting data suggest more of a tendency to manage earnings, with the outcome that the resulting accounting data are potentially less informative (especially about losses) than analogous data for US firms. ${ }^{6}$

Further, we document that the characteristics of reconciled earnings vary based on the domicile of the reporting firm. Evidence of earnings smoothing, delayed loss recognition, small positive earnings and lower correlation with share price tends to be more pronounced in firms from countries that prior research like La Porta et al. (2000) identifies as having weaker local investor protection. Consistent with our primary findings, these results confirm that the SEC's oversight does not entirely overcome the effect of weak investor protection in the local market. Finally, we compare results for cross-listed firms that claim to prepare their local accounts in accordance with US GAAP with those that provide only a reconciliation. While both subsamples suggest evidence of increased earnings management relative to the matched US firms, results are stronger for

interest is in whether their accounting choices result in US-reported data that are less informative and show more evidence of earnings management.

${ }^{6}$ Our approach does not allow us to directly assess whether a firm is violating US GAAP since GAAP, by its very nature, allows some discretion. Rather, as with prior literature like Ball et al. (2000), Leuz et al. (2003) and Lang et al. (2003b) which uses the characteristics of accounting data to draw inference about accounting choices, we can only provide circumstantial evidence that more stringent regulatory oversight is associated with less earnings management and more timely loss recognition. 
the reconciling firms, suggesting that the fact that firms are only required to report a reconciliation (as opposed to providing a full set of US GAAP accounts) provides, at best, a partial explanation for our results.

Our paper sheds light on several findings in the extant literature. For example, one potentially surprising finding from the Form 20-F literature (e.g. Amir et al., 1993) is that the frequency and magnitude of reconciling items is often modest and the value relevance limited. That result seems inconsistent with results in studies like Leuz et al. (2003) which suggest substantial differences in accounting characteristics across countries based on investor protection environments, with the US ranking among the countries with the least earnings management. However, to the extent that, even after the reconciliation, cross-listed firms' US GAAP accounting data differ systematically from data provided by US firms, the limited information content in reconciliation amounts may simply reflect the fact that cross-listed firms are held to different standards than the typical US firm.

Also, our results relate to papers such as Leuz et al. (2003), Ball (2001), Ball et al. (2003) and Bradshaw and Miller (2004) that emphasize the importance of regulatory and legal environments for the characteristics of accounting data. Our results provide evidence that, despite the fact that both our US and non-US samples are required to report net income and shareholders' equity in conformity with US GAAP and both are under the jurisdiction of the SEC, differences in managerial incentives and regulatory environments may affect the characteristics of reported accounting data. This context is particularly interesting because prior research has assumed, in general, that a country's regulatory and legal environments determine reporting choices, and that the SEC is a particularly stringent regulator and the US a particularly onerous legal environment. However, as Siegel (2005) notes, the level of rigor of the US environment may vary based on a company's specific context. ${ }^{7}$ Prior research typically uses country as a proxy for legal

\footnotetext{
${ }^{7}$ Siegel (2005) concludes, "The lesson to be drawn from this analysis is that the rules of the game are different in practice than they are as formally established. Some rules simply cannot be strictly enforced across borders, while the enforcement of other rules could require large resource investments. To understand the institutions, one has to carefully analyze both the formal rules and their informal application. Often the informal application of legal institutions is not what would be predicted by an isolated analysis of formal institutions. This is true even in the U.S., which literature ranks as having some of the strongest and most complete legal institutions in the world, but institutions do not always work in practice as they are ostensibly designed to function."
} 
and regulatory environment, but our results suggest that, even within a country, differences in enforcement and incentives can result in differences in reported accounting data.

Also, our results are related to the cross-listing literature on the "bonding hypothesis" discussed in papers like Coffee (2002) and Siegel (2005). Coffee (2002) surveys the law and financial economics literature and concludes that the evidence is most consistent with firms effectively "renting" the US regulatory environment by subjecting themselves to SEC oversight and litigation exposure by cross listing on US markets. Siegel (2005), however, argues that, while cross listing may entail some "reputational bonding" through voluntary actions undertaken by typical cross-listing firms, the extent of actual "legal bonding" by cross-listed firms may be more limited than often assumed. Our results are broadly consistent with Siegel's argument in that the resulting data for cross-listed firms differ systematically from US firms, suggesting that the underlying incentives and regulatory environments may differ between the two sets of firms. ${ }^{8}$ Further, the fact that the characteristics of reconciled accounting data still reflect the strength of the local investor protection environment suggests that the effect of the added SEC oversight does not entirely compensate for a weak local regulatory environment.

Beyond the academic literature, our research makes several contributions. First, from an investor's perspective, it emphasizes the importance of applying caution in comparing US GAAP reconciled accounting data for cross-listed firms with US GAAP data for US firms since the two sets of results may not be comparable in the sense that cross-listed firms exhibit more evidence of earnings management. Further, our results may be of descriptive interest for standard setting. The SEC requires reconciliations, at least in part, to ensure the comparability and quality of information available to US investors. While results from our analyses clearly cannot resolve the issue of whether

\footnotetext{
${ }^{8}$ The SEC has indicated that it applies "flexibility" for foreign registrants, especially around initial listing dates, in dealing with complex issues like deferred taxes and pensions (Kosnik, 1994). However, none of our observations are from initial listings since we require lagged values in our models. Thus, it seems unlikely that this factor explains our empirical results. Further, it seems unlikely that those types of accounting issues would drive the types of empirical results we document (e.g., small positive profits, timely recognition of losses, or earnings smoothing).
} 
regulatory oversight is set at an appropriate level, they do provide descriptive evidence on the characteristics of the resulting accounting data. ${ }^{9}$

\section{EMPIRICAL DESIGN}

We consider a variety of accounting characteristics that have been suggested in the prior literature. Our focus in determining our measures is on accounting quality and comparability. For expositional convenience, we divide our measures into four related groups: earnings smoothing, management toward earnings targets, timely loss recognition and value relevance.

Because firms self select into cross listing, we are concerned about other factors that might be correlated with the cross-listing decision and might affect the characteristics of accounting data. As a result, we utilize a matched sample based on past sales growth, industry and year. Following Lang et al. (2003b), we match first on year and industry (three-digit SIC code) such that every firm-year is matched exactly on year and industry. We then select the closest firm in terms of sales growth over the previous two years. ${ }^{10}$ We match on industry and growth because the characteristics of earnings, properties of accruals and associations with share price are likely a function of industry and growth. Matching on year should mitigate macroeconomic effects on earnings.

Because we cannot match on all factors that might affect the characteristics of accounting data, we base our analysis, where possible, on regressions which control for other factors that are associated with the cross-listing decision and that might affect reporting. We base our choice of control variables on Pagano et al. (2002), which models the decision to cross list on US markets as a function of firm size, financing structure, growth, need for capital, and frequency of debt and equity issuance. Cross-listed firms

\footnotetext{
${ }^{9}$ Our primary concern is not explicit accounting techniques since, consistent with Bradshaw and Miller (2004), it would be relatively straightforward to document whether a firm has chosen a non-US GAAP accounting technique, but rather with issues where more judgment is required like accruals and reserves. Similarly, international firms might choose different legitimate accounting techniques than US firms (e.g., accelerated versus straight line depreciation). However, given that our measures focus on a range of issues like earnings smoothing, timely loss recognition and small positive earnings, they are less likely to be the result of accounting policy choice and more likely to be the result of decisions on factors over which management has discretion.

${ }^{10}$ The matching procedure is performed separately for every firm-year observation. Thus, the same sample firm may be matched with different US firms in different years.
} 
tend to be larger, so we control for the log of market value of equity as of the end of the year. ${ }^{11}$ In addition, firms may choose to cross list to raise capital, so we include controls for equity and debt issuance (percentage change in common stock and in liabilities during the period, respectively) and for leverage (the ratio of total liabilities to total equity). Further, accruals behavior may vary based on capital intensity, which may also affect the need to raise capital, so we include an asset turnover control (sales for the period divided by year-end total assets). Since accounting characteristics may be affected by cash flows, we also control for cash flows for the period divided by year-end total assets. In addition, we include controls for growth to compensate for cases in which our growth match is imperfect. Finally, we include country fixed effects to control for potential countryspecific omitted variables. $^{12}$

\section{Earnings Smoothing}

A primary concern with accounting internationally, especially in environments where regulation is relatively weak, is a tendency for managers to smooth earnings (Leuz et al., 2003). In part, this likely reflects the fact that, if shareholder protection is not as high a priority, oversight of financial reporting and enforcement will be reduced. Further, managers in weak investor protection environments may have greater incentives to manage earnings. Whatever the cause, research like Leuz et al. (2003) provides evidence that, across a variety of measures, the extent of earnings smoothing appears to be highly correlated with investor protection, with firms from countries with low levels of investor protection exhibiting particularly strong evidence of earnings smoothing and firms from the US exhibiting low levels of smoothing.

Although local contracting is likely based on local-GAAP earnings, manifestations of local incentives and regulation may find their way into reconciled

\footnotetext{
${ }^{11}$ Ideally, we would like to match on size as well as growth because both could affect the characteristics of accounting data. However, it is quite difficult to get a good match on size and growth simultaneously. Thus, in our primary analysis we use the growth match (including controls for size) because the link between growth and accruals is clearest. We also report results using a size match (including controls for growth). Results are not sensitive to the choice of growth or size as a match.

${ }^{12}$ Lang et al. (2003b) also provide evidence on the characteristics of local accounting data for the types of firms that self select into US cross listing. Their evidence suggests that cross-listing firms tend to report "higher quality" local accounting data than other local firms, which should work against the results we document.
} 
earnings for several reasons. First, the existence of an alternate set of data that support a different conclusion may make locally-reported results untenable (Warbrick, 1994). Second, the level of auditing in the local setting may be low relative to the US because of weaker auditing standards and oversight, and reduced legal exposure. Moving to US GAAP reconciliation may not entirely mitigate the issue to the extent that the firm and its auditor perceive that the regulatory and legal environment for cross-listed firms is not as demanding as for US firms.

Because earnings management is difficult to measure, our evidence is necessarily indirect. We begin with a very simple measure, the volatility of earnings deflated by total assets. If firms are smoothing earnings, the variability of earnings should be lower, all else equal. Of course, reported earnings are likely to be sensitive to a variety of other factors. These factors should be at least partially mitigated by our matching procedure and our inclusion of control variables and country fixed effects. To incorporate our controls we first estimate a regression of the change in annual net income (scaled by total assets), pooling the cross-listing and non-cross-listing observations, on the control variables. ${ }^{13}$ We then use the residuals from that regression to compute our measure of earnings variability. ${ }^{14}$ Accordingly, variability of $\triangle N I$ is the variance of the residuals from a regression of the change in annual net income scaled by total assets on the control variables.

Despite our controls, the volatility of earnings may also be affected by firmspecific factors related to the underlying volatility of the cash flow stream. Firms with more volatile cash flows will naturally have more volatile net income. To adjust for the underlying volatility of cash flows, we also conduct an analysis based on the ratio of the variability of net income to the variability of cash flows. Again, controls are included to mitigate the effect of other factors. As in the previous measure, we take a two step approach of first estimating separate regressions of the change in earnings and cash flows on the control variables and then basing the variance estimate on the residuals from the

\footnotetext{
${ }^{13}$ Variables in all of our analyses are winsorized at the $1^{\text {st }}$ and $99^{\text {th }}$ percentiles to control for outliers.

${ }^{14}$ Because it is not clear how best to include controls in the variability analysis (since the variability measure pools across firms and time), we also conducted the analysis without controls and with controlling using a regression approach where the absolute value of the change in earnings and cash flows replaced their raw values to capture cases of extreme earnings (regardless of sign). Results are robust to a range of approaches.
} 
regressions. Our resulting variable, Variability of $\triangle N I$ and $\triangle C F$ is the ratio of the variance of change in net income to the variance of change in net cash flows, with the variances of $\triangle N I$ and $\triangle C F$ based on the residuals from a regression of each variable on the control variables.

A more direct approach to capture the smoothing effect of accruals is to consider their correlation with cash flows. There is naturally a negative correlation between accruals and cash flows, so the primary issue here is with the magnitude of the negative correlation. Papers like Myers and Skinner (2002) and Land and Lang (2002) have argued that, all else equal, a more negative correlation is suggestive of earnings smoothing since managers appear to respond to poor cash flow outcomes by increasing accruals. We measure the correlation of $A C C$ and $C F$ as the partial spearman correlation between the residuals of accruals and the residuals of net cash flow, conditional on our control variables. ${ }^{15}$

\section{Managing Toward Earnings Targets}

Another approach to examining earnings management is to focus on targets toward which firms might manage earnings. A common target in the literature, following from papers like Burgstahler and Dichev (1997), is small positive earnings. Many authors have argued that, given discretion, management will find ways to report small positive earnings if possible. Further, Leuz et al. (2003) show that the presence of small positive earnings is more prevalent in countries with weak investor protection. We measure the percentage of small positive net income $(N I)$ by estimating a regression of an indicator variable set to one for cross-listing and zero for US firms on a small positive $N I$ variable and the control variables. ${ }^{16}$ The small positive $N I$ variable is an indicator set to one for observations for which annual net income scaled by total assets is between 0 and 0.01 and set to zero otherwise. We report the coefficient on the indicator variable as our small

\footnotetext{
${ }^{15}$ Since the variable used as a control for profitability is $\mathrm{CF}$, we exclude the profitability control in this analysis.

${ }^{16}$ In both the analysis of small positive net income and large negative net income, we report results from OLS rather than from a logit analysis because the model rejects the test for homoskedasticity at the $1 \%$ level. Greene (1993) reports that logit models are extremely sensitive to the effects of heteroskedasticity.
} 
positive NI variable. ${ }^{17}$ A positive coefficient suggests that cross-listed firms have more of a tendency to manage earnings toward small positives than do US firms. Again, differences in economic factors affecting the frequency of small positive earnings should be mitigated by our matching procedure and the inclusion of our controls.

\section{Timely Loss Recognition}

Another approach is to consider the evidence of timely loss recognition. Research like Ball et al. (2000) suggests that a primary issue in international contexts is the willingness to recognize large losses as they occur rather than spread their effects over multiple periods. This issue is closely related to earnings smoothing: if earnings are being smoothed, large losses should be relatively rare. We measure the percentage of large negative $N I$ by estimating a regression model, regressing an indicator variable set to one for cross-listing and zero for US firms on a large negative $N I$ variable and the control variables. The large negative $N I$ variable is an indicator set to one for observations for which annual net income scaled by total assets is less than -0.20 and set to zero otherwise. We report the coefficient on the indicator variable from this regression as our large negative NI variable. A negative coefficient is indicative of cross-listed firms being less likely to report large negative earnings. Again, we include our controls to mitigate the effects of other economic factors.

An alternate approach for considering the entire distribution of earnings is to focus on their skewness. Research like Ball et al. (2000) and Ball (2001) suggests that one potential outcome of accounting conservatism is that timely loss recognition results in earnings realizations which tend to be negatively skewed. For example, if firms delay revenue recognition until revenues are earned, while booking large asset impairments when evidence of loss first becomes available, earnings will tend to be negatively skewed. ${ }^{18}$ Accordingly, our skewness of EPS variable is annual earnings per share deflated by price at beginning of the period.

\footnotetext{
${ }^{17}$ We use the cross-listing variable as the dependent variable and small positive earnings as an independent variable because our controls are chosen to explain cross listing choice. However, conclusions are very similar if the small positive indicator is treated as the dependent variable and the cross-listing indicator as an independent variable.

${ }^{18}$ We obtain the significance test from Sheskin (2000).
} 
Another method for inferring the timeliness of earnings is to examine their relation to stock returns. Papers like Basu (1997) consider reverse regressions of earnings on an indicator variable for bad news (negative returns), returns and the interaction of returns with the indicator variable for negative returns. The primary issue is whether the news is captured in earnings in a timely manner. They argue that more timely loss recognition will result in a larger coefficient estimate on bad news earnings in a regression of earnings on returns. We use the magnitude of the coefficient estimate on the interaction between bad news and returns (Basu $\left.R^{*} D U M\right)$ as a measure of the timeliness with which bad news is reflected in earnings. ${ }^{19}$ A larger coefficient is suggestive of more timely loss recognition. Annual returns are computed over the fiscal year and are based on prices from US markets for comparability with the US firms. Because returns are based on relatively long windows, we are less concerned about pricing disparities that may temporarily exist across markets or stale prices.

\section{Value Relevance}

The preceding analyses consider the characteristics of reported earnings without, for the most part, reference to market price. However, another common approach to examine accounting data is based on their association with share price. Papers like Holthausen and Watts (2001) and Barth et al. (2001) discuss strengths and weaknesses of inference based on value relevance. In particular, it is important to note that value relevance tests do not speak to the actual information content of accounting data. Rather, they implicitly assume that accounting data are more informative if they exhibit a higher association with share price or returns.

First, we consider the $\mathrm{R}^{2}$ from a regression of stock price on earnings and book value. Brown et al. (1999) discuss scale issues related to inference from this regression which can occur if samples differ in terms of general share price levels. They recommend deflating the regression variables by past price to mitigate the effect of scale. We regress price as of six months after year-end on book value per share and net income

\footnotetext{
${ }^{19}$ Specifically, Basu $R^{*} D U M$ Coefficient is the coefficient from the regression: $E P S=\alpha+\beta_{1} R+\beta_{2} D U M+$ $\beta_{3} R^{*} D U M+\varepsilon$, where EPS is annual earnings per share deflated by price at the beginning of the period, $R$ is the annual return, and $D U M$ is 1 if the return is negative and 0 otherwise. We also include country fixed effects in this model as well as in the models measuring value relevance. Results are unaffected by the exclusion of the country indicators.
} 
per share. ${ }^{20}$ Our price regression $R^{2}$ variable is the $\mathrm{R}^{2}$ resulting from that regression. Since the average price per share for our cross-listing firms is significantly different than for our US firms, all variables are scaled by price as of six months after the preceding year-end.

An alternate approach based on the timely recognition of losses is to examine a reverse regression, with earnings as the dependent variable and returns as the independent variable. If losses are recognized in a timely manner, the relation between contemporaneous returns and earnings should be stronger, reflecting the fact that more of the information about earnings reaches the market in the period of the loss (as opposed to being postponed to later periods). As argued in Ball et al. (2000), a prediction for good news is more difficult because firms in all environments have incentives to recognize good news in a timely manner. To examine the association between earnings and returns, we estimate a regression of earnings on returns, splitting between cases of negative and positive returns. ${ }^{21}$ Our Basu Regression $R^{2}$ variable is the $\mathrm{R}^{2}$ resulting from that regression. If earnings are managed more for non-US firms, we predict a lower association between returns and earnings for these firms, especially for bad news.

\section{EMPIRICAL RESULTS}

\section{Sample}

Our sample comprises 698 non-US firm years (181 firms) for which Form 20-F, CRSP and Compustat data were available over the period 1991 through 2002. We obtain our sample from the Bank of New York Global Equity Investing Depository Receipt Service list and gather US GAAP-reconciled data from Forms 20-F. We limit our sample to Level II and III depository receipts trading on the NYSE, AMEX or NASDAQ since they are required to file reconciliations. We compare the cross-listed firms with a sample

\footnotetext{
${ }^{20} P=\alpha+\beta_{1} B V P S+\beta_{2} N I P S+\varepsilon$ where $P$ is price as of six months after the fiscal year-end, BVPS is book value of shareholders' equity per share, and NIPS is net income per share. All variables are scaled by price as of six months after the preceding year-end.

${ }^{21} E P S=\alpha+\beta R+\varepsilon$, where EPS is annual earnings per share deflated by price at beginning of the period and $R$ is the annual return estimated separately for $R$ negative (bad news) and $R$ nonnegative (good news).
} 
of US firms, matched on year, industry and growth, and control for other firm characteristics suggested by Pagano et al. (2002) as well as country fixed effects.

\section{[INSERT TABLE 1 HERE]}

Table 1, panel A includes descriptive data for our sample firms in terms of country representation. In general, the sample firms are spread across a wide range of countries, with greatest representation from England and Japan. ${ }^{22}$ Panel B of table 1 reports representation by industry. The sample is also comprised of a range of industries, with most firms in manufacturing, construction or utilities. However, given our matching criteria, industry effects should be naturally controlled.

\section{[INSERT TABLE 2 HERE]}

Table 2, panel A presents descriptive information on the test and control variables for the sample firms. Not surprising, given the matching criteria, the two samples are similar in terms of sales growth. Mean leverage across the two samples is not statistically different, although median leverage is higher for the cross-listed firms than for the matched US sample. Equity issuance is not statistically different for the two samples. Median debt issuance is similar for the two samples, but the mean is higher for the US firms. Asset turnover is significantly higher for the US firms, suggesting that the non-US firms are more capital intensive. Finally, the cross-listed firms are significantly larger than the US firms. While there is substantial overlap in the size distributions and we control for size in our tests, we also replicate the analysis based on a size-matched sample (where size is not significantly different between the sample and control firms) with very similar results. ${ }^{23}$ In terms of the test variables, several are significantly different across subsamples. The change in net income is significantly lower for US firms suggesting that the growth in profits was lower, although the difference in change in operating cash flow is not significantly different, potentially explained by the lower mean accruals for the US firms. Also, US firms have fewer small positive net income observations and more large negative net income observations, consistent with less evidence of earnings management.

\footnotetext{
${ }^{22}$ We perform analyses (not tabulated) on a sample that excludes England and Japan to ensure that our results are not driven by just a few countries, with similar results.

${ }^{23}$ For the other control variables where there are significant differences between samples (leverage, debt issuance and asset turnover), we conducted sensitivity analyses excluding observations with the poorest matches. This process left samples where the differences were no longer significant. Results were robust to excluding those observations.
} 
Table 2, panel B provides a correlation matrix for the variables, with Spearman correlations in the upper quadrant and Pearson correlations in the lower quadrant. Correlations between the variables are generally modest suggesting that multicollinearity is not a substantive issue.

\section{Results}

Table 3, panels A through D presents our primary results for earnings smoothing, managing toward earnings targets, timely loss recognition and stock price associations. For expositional convenience, panels A through D present results for the primary relations of interest. Table 3, panel E includes coefficient estimates and significance levels for the control variables.

\section{[INSERT TABLE 3 HERE]}

\section{Earnings Smoothing}

Results for earnings smoothing measures are reported in panel A. In terms of the primary relations of interest, the tests of net income variability in panel A suggest that earnings are less volatile for the non-US firms who cross list than for the US firms, after controlling for other factors. The variability of net income is substantially greater for the US firms than for the cross-listed firms, and this difference is statistically significant at the .01 level. In terms of the control variables from the first stage regressions reported in panel $\mathrm{E}$, the change in net income is decreasing in size, asset turnover and profitability, but is increasing in debt issuance. Results are not sensitive to the inclusion of the control variables.

Similar conclusions follow from the ratio of earnings variability to cash flow variability. From panel E, the same basic factors that affect the change in net income also affect the change in cash flows. After controlling for other factors, cash flow variability (not tabulated) is similar for the two samples, so taking the ratio of net income variability to cash flow variability yields similar conclusions to those for net income variability. We do not know of a formal statistical test for differences in the ratios of variances. 
However, as indicated in table 3, panel A, the ratio of net income variability to cash flow variability is substantially lower for the cross-listed firms than for the US firms. These results suggest that the smoother earnings stream observed for the cross-listed firms is not a result of a smoother cash flow stream, but rather, is driven by the effect of accruals.

The correlation between cash flows and accruals focuses more directly on the timing of accruals. Table 3, panel A provides evidence that cross-listed firms are more likely to use accruals to manage earnings than US firms. The partial correlation between cash flows and accruals conditional on our control variables is significantly more negative for the cross-listed firms than for the US firms, as expected. ${ }^{24}$ This result likely helps explain why the earnings stream tends to be smoother than the cash flow stream for cross-listed firms relative to US firms: shortfalls in cash flows are offset by higher accruals. In terms of the control variables reported in panel E, accruals are positively correlated with firm size and asset turnover, and negatively correlated with equity and debt issuance. Cash flows are positively correlated with equity and debt issuance. Results are not sensitive to inclusion of the control variables.

\section{Managing Toward Earnings Targets}

The preceding results suggest that cross-listed firms are more likely to smooth earnings than are US-domiciled firms. A related question is how such accruals management might affect the resulting distribution of earnings. As discussed earlier, authors beginning with Burgstahler and Dichev (1997) have argued that firms will have particular incentives to manage towards small positive earnings. Panel B of table 3 reports results from the regression analysis of small positive NI. Consistent with the descriptive results in table 2 , the proportion of small positive earnings is significantly greater for cross-listed firms than for US firms. This result suggests that cross-listed firms are more likely to manage earnings towards positive targets than are US firms.

\section{Timely Loss Recognition}

A related question is how the smoothness of earnings is manifested in the timely recognition of losses. Results in table 3, panel C are generally consistent with non-US

\footnotetext{
${ }^{24}$ We base all tests of differences in $\mathrm{R}^{2}$ measures using the approach in Cramer (1987).
} 
firms having greater incentives to manage earnings to avoid large losses. Although we do not know of a formal statistical test comparing skewness for two samples, the results suggest that earnings for US firms are more negatively skewed than for cross-listed firms. Further, skewness for the US firms is significantly negative while skewness for the nonUS firms is positive. These results are generally consistent with more timely loss recognition for the US firms, as are the results for the frequency of large negative earnings observations. The incidence of large negative earnings is significantly lower for the cross-listed firms, suggesting that cross-listed firms smooth earnings by delaying the effects of large negative outcomes relative to US firms.

Similar conclusions obtain based on the Basu-style analysis of timely loss recognition. In particular, we regress earnings on returns, a bad news indicator, and the interaction of these two variables. If earnings are a timely source of information on losses, the coefficient on the interaction variable should be larger for US firms than for the non-US sample. Table 3, panel C presents the results for the coefficient of interest. The coefficient estimate on the interaction term for US firms is twice that for non-US firms, and the difference is statistically significant at the .01 level. Coefficients on returns and the bad news indicator, reported in table 3, panel E, are not statistically significant.

Overall, the tests of timely loss recognition complement those for earning smoothing. Both suggest that not only is there more evidence of earnings smoothing in non-US firms, but smoothing appears to come at the expense of timely loss recognition. One interpretation of the results is that managers of cross-listing firms smooth away from large negative earnings and toward small positive earnings, resulting in less timely recognition of losses.

\section{Value Relevance}

Our final tests assess the degree of association between accounting data and stock prices. Table 3, panel D presents results for the value relevance tests. First, comparing a regression of price on earnings and book value for the US firms with the non-US firms, the $\mathrm{R}^{2}$ for the US firms is significantly greater (at the .01 level) than for the non-US 
firms. ${ }^{25}$ Coefficients on book value and earnings for both samples, reported in table 3, panel E, are positive and significant, although they are smaller for the cross-listed firms. Overall, the results suggest that accounting data are more value relevant for US than for cross-listed firms.

Similar conclusions obtain for the $\mathrm{R}^{2} \mathrm{~s}$ from a regression of earnings on returns. As suggested in Ball et al. (2000), we split the sample into two groups based on good and bad news. The association between earnings and returns is significantly higher for the US firms than for the cross-listed firms for bad news, and is insignificantly higher for good news. The stronger results for bad news are consistent with the Ball et al. (2000) observation that the effects of the institutional environment are likely to be most pronounced for bad news observations.

\section{Robustness}

One concern with the preceding analysis is the difference in firm size between the two samples. As noted earlier, a tradeoff in matching on growth is that our cross-listed firms are generally larger than their US matches. While it is not clear that this would bias the results and we include controls for size where possible in our analysis, the difference in size between samples is large enough to be potentially troubling. To mitigate concerns about size, we replicate the analysis matching on year and industry (as before) and on size. For the size-matched sample, mean (median) size is $\$ 5,943$ million (\$4,403 million) for the cross-listed firms, versus $\$ 5,653$ million ( $\$ 3,984$ million) for the US firms, differences that are not statistically significant. To control for the differences in growth (and other characteristics that affect the cross-listing decision) between the size-matched samples, we continue to include the same controls as in the previous analysis.

\section{[INSERT TABLE 4 HERE]}

Results from the size-matched analysis are reported in table 4. Overall, conclusions are very similar to those reported in table $3 .^{26}$ The variability of net income

\footnotetext{
${ }^{25}$ Recall that all variables are deflated by previous year price to mitigate scale bias, which reduces the $\mathrm{R}^{2}$ values.

${ }^{26}$ Coefficient estimates on controls, which are generally similar to those reported in table 3, panel E, are not reported for the sake of brevity.
} 
remains higher for the US firms, both in absolute terms and relative to cash flows. ${ }^{27}$ Similarly, the correlation of accruals and cash flows is significantly more negative for the cross-listing firms than for the size-matched US sample and the percentage of small positive earnings is significantly higher. In terms of timely loss recognition, there is a significantly greater tendency toward large losses for the size-matched US firms relative to the cross-listed firms, and earnings are more negatively skewed for the size-matched US firms. In addition, the Basu model coefficient is significantly larger for the sizematched US firms. Finally, the degree of association between returns and bad news earnings is higher for US firms than for cross-listed firms. The only differences relative to the growth-matched analysis are that the difference in the degree of association between returns and good news earnings, which had been insignificant in the earlier analysis, is now significant and the difference in the association between price and accounting data, which had been significant in the earlier analysis, is positive but not statistically significant.

An alternate approach to examine the effect of potential size mismatches in table 3 is to split our sample between cases in which the difference in size between the crosslisting firm and its US match are most pronounced and cases in which the size match is closer. To the extent that size mismatches are important, results should be stronger in cases where the size match is worse. Results from that analysis (not tabulated) suggest that conclusions are very similar for both groups of firms. Further, there is no evidence of a pattern in the strength of results across the two groups, suggesting that the size match does not drive the empirical results.

Another potential concern with our analysis is that there are, on average, 3.85 observations per firm, creating the possibility of correlated residuals. Residual autocorrelation should not affect the direction or magnitude of our results, but could affect significance levels. Given the range of measures we apply, we do not know of a way to correct for autocorrelation. Instead, we re-estimate the analysis using only one observation per firm. That is extreme because it sacrifices the information in the other observations and substantially reduces the sample size. However, results using only one

\footnotetext{
${ }^{27}$ The results for the cross-listed firms in panel A of tables 3 and 4 are slightly different because these analyses utilize a pooled regression of both cross-listed and non-cross-listed firms.
} 
observation per firm (not tabulated) are consistent with those reported above. Of our ten measures, only the variability of $\Delta N I$ and the large negative NI measures lose significance (although the direction of both remains consistent).

\section{Supplementary Analyses}

The preceding suggests that, across a wide range of measures, US GAAPreconciled earnings for cross-listed firms are characterized by greater evidence of earnings management, less timely recognition of losses and a lower association with share price than earnings for US firms. However, the analysis is based on an aggregation of observations across a wide range of companies from countries with differing institutional environments, suggesting that the strength of the relation likely differs across sample firms.

One notable difference that is likely to exist across sample firms is the local regulatory environment. We know from prior research, such as Leuz et al. (2003), that reporting in the local market is a function of the local regulatory environment. If cross listing into the US market effectively constitutes "renting US securities laws" (Coffee, 2002), we might expect the US environment to supplant the local environment so that, for cross-listed firms, the local regulatory environment is no longer a significant determinant of the characteristics of reconciled accounting data. If, on the other hand, the effect of cross listing is more limited (as our prior results suggest), we would expect to see effects of the local regulatory environment still evident in the reconciled accounts, with countries with relatively weak local investor protection showing the strongest evidence of earnings management in the reconciled data.

There are a number of ways that an analysis across different institutional environments could be structured. We follow the analysis in La Porta et al. (1998) and compare firms based on their measure of outside investor rights. All else equal, prior literature suggests that improved investor protection results in greater oversight of the accounts and, therefore, less latitude exists for earnings management. The assigned grouping for each country is presented in panel A of table $1 .{ }^{28}$ Firms that have investor

\footnotetext{
${ }^{28}$ A small number of observations are from countries for which ratings from La Porta et al. (1998) are not available. We assign those from China, Dominican Republic, Hungary, Ghana and countries in South
} 
protection scores of two or less are assigned to the low investor protection sample, while firms with investor protection scores above two are assigned to the high investor protection sample. $^{29}$

\section{[INSERT TABLE 5 HERE]}

Results for the high/low investor protection split are reported in table 5. Two conclusions are notable. First, the conclusions for the sample as a whole are generally robust for both subsamples. This result provides some confidence that the results are not driven by a subset of countries or environments. ${ }^{30}$ For example, the earnings management variable results are consistent for both subsamples, with the exception of percentage of small positive earnings which is no longer significant for the low investor protection subsample. Similarly, there tends to be less evidence of timely loss recognition and a lower association between accounting data and stock prices for both cross-listed subsamples relative to their US matches. As a result, it does not appear that our results are driven by either subset of countries.

More importantly for our purposes, for most of the measures the gap between the cross-listed and US firms is larger for the observations from low investor protection countries than for the high investor protection countries. For all measures other than percentage of small positive earnings, the gap between cross-listed and US firms is statistically significant for low investor protection firms while the difference is no longer significant for several of our measures (large negative net income, skewness of EPS, Basu regression coefficient and Basu bad news $\mathrm{R}^{2}$ ) for the high investor protection subsample. While we do not know of a formal test for an overall comparison across the two subsamples, the results suggest that the differences in earnings management are strongest in environments in which local investor protection is weak. The fact that the

\footnotetext{
America to the low investor protection sample, and those from New Zealand and Israel to the high investor protection sample. Results are not sensitive to inclusion of these observations.

${ }^{29}$ Because there are a variety of potential measures of investor protection, an alternate approach would be to segment the countries based on an empirical measure of local earnings management which would reflect the confluence of influences in the local market. While such an approach has the advantage of including a broader set of regulatory effects, it increases the likelihood of omitted correlated variable bias because any omitted variables in the original categorization would likely affect the inference from the cross listing comparison. However, empirically, our results (not tabulated) are very similar if countries are segmented based on the earnings management results in Leuz et al. (2003).

${ }^{30}$ The fact that similar (although weaker) results obtain for the high investor protection countries is consistent with the Leuz et al. (2003) finding that earnings management for US firms tends to be low even relative to other high investor protection countries.
} 
reconciled accounting data still reflect effects of the local investor protection environment suggests that, while the added scrutiny by the SEC may mitigate earnings management in the reconciled amounts, the local regulatory environment remains important. $^{31}$

Closely related, even firms within a country may differ based on the accounting standards applied in the local environment. Forty-six of the sample firms indicate that they apply US GAAP in their primary accounts rather than local GAAP. A majority of these observations are for Japanese firms that were traditionally permitted to report under US GAAP because Japanese GAAP did not allow for consolidation. ${ }^{32}$ While the sample size is small and is concentrated in a few countries, the characteristics of accounting data for these firms potentially differ from firms that only reconcile to US GAAP because the firms' claimed consistency with US GAAP may receive additional scrutiny. As a result, this sample may provide some insight into whether it is a difference in auditor oversight that results in greater earnings management. From the SEC's perspective, the two approaches should yield similar results since the ultimate standard is the same whether a firm files local accounts in accordance with US GAAP or reconciles accounts to US GAAP. However, if local accounts claimed to be in compliance with US GAAP attract additional local auditor scrutiny, one might expect accounting data for those firms to be more similar to US firms than for firms reconciling to US GAAP.

\section{[INSERT TABLE 6 HERE]}

Table 6 presents results for the firms applying US GAAP in their primary accounts. Two points are worth noting. First, results for the US GAAP firms are generally consistent with the sample as a whole. In particular, all results for the US GAAP subsample are directionally consistent with the analysis for the entire sample, with the exception of the large negative net income coefficient which is insignificant. As a

\footnotetext{
${ }^{31}$ One potential conclusion from the preceding is that our observed results are more likely driven by regulatory environment than managerial incentives because they vary with local investor protection. However, as with Leuz et al. (2003), we cannot be sure that is the case because local investor protection environment is endogenous and possibly evolves as a result of local earnings management incentives.

32 This subsample of firms provides an interesting potential overlap with Bradshaw and Miller (2004). They document that, among non-US firms that claim to use US GAAP in their local accounts, those that also cross list on the US market are more similar to US firms than those that do not. Our results suggest that, while these firms may be more similar to US GAAP than other firms in the local environment, they still show more evidence of earnings management than the typical US firm.
} 
consequence, the same general conclusion appears to hold for the subset of firms that adopt US GAAP in their primary accounts: there is still more evidence of earnings management than for US firms.

Second, however, the strength of the evidence is weaker for this subsample. The magnitudes of the differences between the cross-listed and US firms is generally reduced relative to the full sample and some of the relations are no longer significant (variability of net income relative to cash flows, correlation of cash flows and accruals, skewness of EPS and the association between returns and bad news earnings). As a consequence, while there is somewhat greater evidence of earnings management for even the firms that claim to report local accounts under US GAAP, the evidence is weaker than for the sample as a whole. Subject to the caveat that the sample size here is relatively small and is clustered in a few countries, the results suggest that, although the evidence of earnings management is most pronounced for firms that reconcile, the general issue appears to pertain to cross-listing firms more generally. To the extent that US GAAP firms attract greater scrutiny in their local environment, this evidence again suggests that the local regulatory environment affects the reconciled accounting data.

In addition to regulatory issues, it is possible that differences exist based on managerial reporting incentives related to the demand for information in the US market. If managers in a cross-listed firm perceive that there is little interest from US investors, they may be more willing to provide low quality reports. A difference in investor interest in and of itself should not explain our results since firms are required to comply with US GAAP irrespective of investor base, but it is possible that firms with a greater US investor base perceive greater pressure to report more similarly to US firms. To investigate the effect of investor base, we divided the sample into low and high float subsamples based on the number of shares covered by ADRs relative to total shares outstanding worldwide. A problem with this approach is that ADRs represent a relatively small fraction of shares outstanding and trading volume for most ADR firms. As a consequence, it is not clear how important US market pressure would be for the typical cross-listed firm. Perhaps reflecting the relatively low US float, results for both subsamples (not tabulated) are quite similar in the sense that both exhibit greater evidence of earnings management relative to the matched US firms. Comparing the two 
subsamples, there is no clear evidence of patterns across the two samples. There is evidence of higher quality for the high float firms in terms of the associations between accounting data and share price and in terms of timely loss recognition, but the measures of earnings variability are mixed. As a consequence, there is at best weak evidence that the extent of US float is a determinant of the characteristics of accounting data in this context, perhaps reflecting the relatively modest presence of the typical cross-listed firm on the US market.

Managerial reporting incentives are also potentially correlated with the length of time the firm has traded on US markets, as firms that have traded longer may perceive more investor interest. Further, increased familiarity with US norms may naturally lead to accounting choices that are more similar to those made by US firms. Ideally, it would be interesting to conduct an "event study" after the cross listing dates to see if original differences dissipate or are exacerbated over time. The prediction here is not clear because, on the one hand, increased SEC and auditor scrutiny around the original cross listing could induce cross-listed firms to provide higher quality reporting. On the other hand, firms may gravitate toward higher quality reporting the longer they trade on the US markets.

As a practical matter, the data do not lend themselves to a true time series comparison because we have a relatively small number of observations for most firms and many firms began cross listing either too early or too late to allow a before-and-after comparison. However, it is possible to segment our sample based on the number of years since cross listing, recognizing that this means that the sample composition is not held constant between subperiods. For our sample, the median firm has been cross listed for about six years, so we apply that as a cutoff. Given that most of our sample firms (even in the recent cross-listing sample) have been cross listed for a substantial period, we may not have enough observations close to the cross-listing date to conduct a strong test. Results for the two subsamples (not tabulated) are very similar in the sense that both suggest significant differences relative to their US matches. Further, where differences do exist, there is no clear pattern, suggesting that, at least based on the cutoff we use, differences are quite consistent over time. It is possible that any seasoning occurs prior to 
our cutoff. Alternatively, it is possible that firms make their primary accounting choices at the time of the cross listing and do not modify them much subsequently.

Subject to the caveat that the sample sizes are small and the tests relatively weak, results in this section are interesting because they provide evidence that the characteristics of the US-reported accounting data are affected by the local regulatory environment, but they provide little evidence that they are a function of incentives created by the US trading environment.

\section{CONCLUSIONS}

Our goal was to investigate the characteristics of reconciled US GAAP accounting data for cross-listed firms. Our results suggest that, across a wide range of measures, accounting data for cross-listed firms show more evidence of earnings management, less evidence of timely loss recognition and a lower association with share price. While it is dangerous to draw assessments about accounting quality from these sorts of measures, as a group they provide at least some evidence of differences along dimensions that may affect the informativeness of accounting data. Further, the results are consistent with research like Leuz et al. (2003) in the sense that they find that firms in weaker investor protection environments exhibit more evidence of earnings management. Consistent with the notion that the regulatory and legal environment is less arduous for cross-listed firms and incentives to manage earnings are stronger, our evidence suggests that the earnings management is more of an issue for cross-listed firms than for US firms. Our results from splitting cross-listing observations by country of origin suggest that evidence of earnings management is strongest for firms with the weakest local investor protection. This result is consistent with reconciled US GAAP reporting being influenced by the local reporting and regulatory environment. Further, results are consistent when the sample is split based on whether cross-listed firms reconcile to US GAAP or prepare local accounts in accordance with US GAAP (although results are stronger for reconciling firms) suggesting that the fact that most firms provide only a reconciliation to US GAAP is, at best, a partial explanation for the results. 
While we do not intend our results to provide normative guidance, we believe that they provide some interesting empirical implications. If our results do, in fact, reflect the effects of earnings management, they suggest some issues for standard setters. For example, is the goal of providing comparable, high quality, accounting data being met? Is there the potential that, as some have suggested, accounting data for cross-listed firms provide the illusion, but not the substance, of comparability? If an attraction of US listing is "reputational bonding," might additional oversight be merited? While our analysis cannot answer those sorts of questions, it at least suggests potential issues of interest.

Further, our results highlight the conclusion in papers like Ball et al. (2003) that nominally similar accounting requirements do not necessarily result in comparable accounting data if underlying institutional differences are important. An interesting issue is that our results come in the context of the US regulatory and legal environment, which has a reputation for being particularly demanding. However, our results suggest that, even in an environment like the US, differences in underlying institutional environments can significantly affect reported results. Also, the results suggest that, even among firms sharing a common US regulatory and legal environment, reporting may differ depending on managerial incentives and the extent of enforcement and legal exposure.

Finally, our results highlight the importance of applying care in considering crosslisting decisions going forward. A controversial aspect of the recent Sarbanes Oxley Act has been the requirement that auditing firm regulation and the attestation of results by management apply to both US and cross-listed firms. The issue has been exacerbated by recent accounting scandals involving international firms like Parmalat. While our results cannot address whether those types of requirements are excessive, they do suggest that if the goal is to provide comparable accounting data of similar quality for US and crosslisted firms, it may be important to ensure that managers and auditors are held to similar standards. 


\section{REFERENCES}

Amir, E., Harris, T., Venuti, E., 1993. A Comparison of the Value-Relevance of U.S. versus Non-U.S. GAAP Accounting Measures Using Form 20-F Reconciliations. Journal of Accounting Research 31, 230-275.

Ball, R., 2001. Infrastructure Requirements for an Economically Efficient System of Public Financial Reporting and Disclosure. Brookings-Wharton Papers on Financial Services, 127-169.

Ball, R., Kothari, S.P., Robin, A., 2000. The Effect of International Institutional Factors on Properties of Accounting Earnings. Journal of Accounting and Economics 29, $1-51$.

Ball, R., Robin, A., Wu, J., 2003. Incentives versus Standards: Properties of Accounting Income in Four East Asian Countries, and Implications for Acceptance of IAS. Journal of Accounting and Economics 36, 235-270.

Barth, M., Beaver, W., Landsman, W., 2001. Relevance of Value Relevance Literature for Financial Accounting Standard Setting: Another View. Journal of Accounting and Economics 31, 77-104.

Basu, S., 1997. The Conservatism Principle and the Asymmetric Timeliness of Earnings. Journal of Accounting and Economics 24, 3-37.

Bradshaw, M., Miller, G., 2004. Will Harmonizing Accounting Standards Really Harmonize Accounting? Evidence from Non-U.S. Firms Adopting US GAAP. Working paper, Harvard Business School.

Breeden, R., 1994. Foreign Companies and U.S. Markets in a Time of Economic Transformation. Fordham International Law Journal 17.

Brown, S., Lo, K., Lys, T., 1999. Use of $\mathrm{R}^{2}$ in Accounting Research: Measuring Changes in Value Relevance over the last Four Decades. Journal of Accounting and Economics 28, 83-115.

Burgstahler, D., Dichev, I., 1997. Earnings Management to Avoid Earnings Decreases and Losses. Journal of Accounting and Economics 24, 99-126.

Coffee, J., 2002. Racing Towards the Top?: The Impact of Cross-Listing and Stock Market Competition on International Corporate Governance. Working paper, Columbia University Law School.

Cramer, J., 1987. Mean and Variance of $\mathrm{R}^{2}$ in Small and Moderate Samples. Journal of Econometrics 35, 253-66. 
Frost, C., Pownall, G., 1994, "Accounting Disclosure Practices in the United States and the United Kingdom”, Journal of Accounting Research, Volume 32 No. 1 (Spring): $75-102$.

Greene, W., 1993. Econometric Analysis. MacMillan, New York.

Holthausen, R., Watts, R., 2001. Relevance of Value Relevance Literature for Financial Accounting Standard Setting. Journal of Accounting and Economics 31, 3-75.

Jenkins, E., 1999. Financial reporting in a global capital market world. Financial Accounting Series, No. 198-A (June 29), 2-6.

Kosnik, R., 1994. The Role of the SEC in Evaluating Foreign Issuers Coming to the U.S. Markets. Fordham International Law Journal 17, s97-s111.

La Porta, R., Lopez-de-Silanes, F., Schleifer, A., Vishny, R.,1998. Law and finance. Journal of Political Economy 106, 1113-1155.

La Porta, R., Lopez-de-Silanes, F., Shleifer, A., Vishny, R., 2000. Investor protection and corporate governance. Journal of Financial Economics 58, 3-27.

Land, J., Lang, M., 2002. Empirical Evidence on the Evolution of International Earnings. Accounting Review 77, 115-134.

Lang, M., Lins, K., Miller, D., 2003a. ADRs, Analysts, and Accuracy: Do ADRs Improve a Firm's Information Environment and Lower its Cost of Capital? Journal of Accounting Research.

Lang, M., Raedy, J., Yetman, M., 2003b. How Representative are Firms that are Cross Listed in the United States? An Analysis of Accounting Quality. Journal of Accounting Research 41, 363-386.

Leuz, C., Nanda, D., Wysocki, P., 2003. Earnings Management and Investor Protection: an International Comparison. Journal of Financial Economics 69, 505-527.

Licht, A., 2000. Genie in a bottle? Assessing managerial opportunism in international securities transactions. Columbia Business Law Review 2000, 51-120.

Licht, A., 2003. Cross-listing and corporate governance: bonding or avoiding?" Chicago Journal of International Law 4, 141-163.

Myers, L., Skinner, D., 2002. Earnings Momentum and Earnings Management. Working paper, University of Michigan.

Pagano, M., Röell, A., Zehner, J., 2002. The Geography of Equity Listings: Why do Companies List Abroad? Journal of Finance 57, 2379-2856. 
Sheskin, D, 2000. The Handbook of Parametric and Nonparametric Statistical Procedures. Chapman and Hall/CRC, Boston.

Siegel, J., 2005. Can Foreign Firms Bond Themselves Effectively by Renting U.S. Securities Laws?, Journal of Financial Economics 75: 319-359..

Warbrick, M., 1994. Practical Company Experience in Entering U.S. Markets:

Significant Issues and Hurdles from the Issuer's Perspective. Fordham International Law Journal 17, s112-s119. 
TABLE 1

Frequencies of Cross-Listed and US Matched Firms

\begin{tabular}{|c|c|c|c|c|}
\hline \multirow[b]{2}{*}{ Country } & \multicolumn{3}{|c|}{ Panel A: Home Country Analysis } & \multirow[b]{2}{*}{$\begin{array}{l}\text { Number of } \\
\text { Unique Cross- } \\
\text { Listed Firms }\end{array}$} \\
\hline & $\begin{array}{l}\text { Level of } \\
\text { Investor } \\
\text { Protection }^{\mathrm{a}}\end{array}$ & $\begin{array}{c}\text { Number of } \\
\text { Firm-Year } \\
\text { Observations }\end{array}$ & $\begin{array}{l}\text { Percentage of } \\
\text { Firm-Year } \\
\text { Observations }\end{array}$ & \\
\hline Argentina & LOW & 20 & 2.87 & 6 \\
\hline Australia & HIGH & 33 & 4.73 & 7 \\
\hline Brazil & LOW & 1 & 0.14 & 1 \\
\hline Chile & LOW & 30 & 4.30 & 12 \\
\hline China & LOW & 14 & 2.01 & 8 \\
\hline Denmark & LOW & 15 & 2.15 & 3 \\
\hline Dominican Republic & LOW & 1 & 0.14 & 1 \\
\hline England & HIGH & 196 & 28.08 & 42 \\
\hline Finland & LOW & 6 & 0.86 & 2 \\
\hline France & LOW & 25 & 3.58 & 12 \\
\hline Germany & LOW & 6 & 0.86 & 2 \\
\hline Ghana & LOW & 2 & 0.29 & 1 \\
\hline Greece & LOW & 7 & 1.00 & 1 \\
\hline Hong Kong & HIGH & 3 & 0.43 & 1 \\
\hline Hungary & LOW & 1 & 0.14 & 1 \\
\hline Ireland & HIGH & 19 & 2.72 & 5 \\
\hline Israel & HIGH & 10 & 1.43 & 5 \\
\hline Italy & LOW & 22 & 3.15 & 6 \\
\hline Japan & HIGH & 112 & 16.05 & 13 \\
\hline Mexico & LOW & 52 & 7.45 & 19 \\
\hline Netherlands & LOW & 37 & 5.30 & 8 \\
\hline New Zealand & HIGH & 2 & 0.29 & 1 \\
\hline Norway & HIGH & 11 & 1.58 & 3 \\
\hline Peru & LOW & 3 & 0.43 & 2 \\
\hline Philippines & LOW & 5 & 0.72 & 1 \\
\hline Portugal & HIGH & 5 & 0.72 & 2 \\
\hline Singapore & HIGH & 1 & 0.14 & 1 \\
\hline South Africa & HIGH & 2 & 0.29 & 1 \\
\hline South Korea & LOW & 9 & 1.29 & 3 \\
\hline Spain & HIGH & 10 & 1.43 & 2 \\
\hline Sweden & LOW & 29 & 4.15 & 4 \\
\hline Switzerland & LOW & 1 & 0.14 & 1 \\
\hline Taiwan & HIGH & 2 & 0.29 & 1 \\
\hline Venezuela & LOW & $\underline{6}$ & $\underline{0.86}$ & $\underline{3}$ \\
\hline Totals & & 698 & 100.00 & 181 \\
\hline
\end{tabular}

${ }^{a}$ LOW is low investor protection and HIGH is high investor protection. These classifications are based predominantly on La Porta et al. (1998). A small number of observations are from countries for which ratings are not available. We assign those from China, Dominican Republic, Hungary, Ghana and countries in South America to the low investor protection sample, and those from New Zealand and Israel to the high investor protection sample. 


\section{Panel B: Industry Analysis}

\begin{tabular}{|c|c|c|c|c|}
\hline Industry & $\begin{array}{l}\text { Number of } \\
\text { Firm-Year } \\
\text { Observations }\end{array}$ & $\begin{array}{l}\text { Percentage of } \\
\text { Firm-Year } \\
\text { Observations }\end{array}$ & $\begin{array}{l}\text { Number of } \\
\text { Unique Cross- } \\
\text { Listed Firms }\end{array}$ & $\begin{array}{c}\text { Number of } \\
\text { Unique US } \\
\text { Firms }\end{array}$ \\
\hline Agriculture, Forestry and Fishing & 3 & 0.43 & 2 & 3 \\
\hline Mining & 48 & 6.88 & 14 & 32 \\
\hline Construction & 171 & 24.50 & 45 & 106 \\
\hline Manufacturing & 201 & 28.80 & 40 & 158 \\
\hline Utilities & 150 & 21.49 & 46 & 91 \\
\hline Wholesale Trade & 42 & 6.02 & 14 & 29 \\
\hline Retail Trade & 21 & 3.01 & 4 & 19 \\
\hline Finance, Insurance and Real Estate & 49 & 7.02 & 12 & 40 \\
\hline Services & 4 & 0.57 & 2 & 4 \\
\hline Public Administration & $\underline{9}$ & $\underline{1.29}$ & $\underline{2}$ & $\underline{6}$ \\
\hline Totals & 698 & 100.00 & 181 & 488 \\
\hline
\end{tabular}


TABLE 2

Descriptive Statistics

Panel A: Univariate Statistics $(\mathrm{N}=698)$

\begin{tabular}{|c|c|c|c|c|c|c|c|c|c|c|}
\hline \multirow[b]{2}{*}{ Variable $^{\mathrm{a}}$} & \multicolumn{5}{|c|}{ Cross-Listed Firms } & \multicolumn{5}{|c|}{ US Firms } \\
\hline & Mean & Median & $\begin{array}{l}\text { Standard } \\
\text { Deviation }\end{array}$ & Q1 & Q3 & Mean & Median & $\begin{array}{l}\text { Standard } \\
\text { Deviation }\end{array}$ & Q1 & Q3 \\
\hline \multicolumn{11}{|l|}{ Test Variables: } \\
\hline CHANGE_NI & 0.00 & 0.00 & 0.17 & -0.02 & 0.02 & $-0.02 * * *$ & $-0.01 * *$ & 0.14 & -0.03 & 0.02 \\
\hline CHANGE_CF & 0.00 & 0.00 & 0.10 & -0.02 & 0.03 & 0.00 & 0.00 & 0.18 & -0.02 & 0.03 \\
\hline TOTACC & 0.04 & 0.04 & 0.11 & 0.00 & 0.07 & $-0.01 * * *$ & 0.03 & 0.20 & -0.03 & 0.07 \\
\hline$C F$ & 0.00 & 0.00 & 0.07 & -0.01 & 0.02 & 0.01 & 0.00 & 0.13 & -0.01 & 0.02 \\
\hline$L A R G E N E G$ & 0.01 & 0.00 & 0.11 & 0.00 & 0.00 & $0.07 * * *$ & 0.00 & 0.26 & 0.00 & 0.00 \\
\hline ANNRET & 0.18 & 0.09 & 0.66 & -0.13 & 0.34 & 0.21 & 0.06 & 1.16 & -0.22 & 0.33 \\
\hline$E P S$ & 0.04 & 0.04 & 0.16 & 0.01 & 0.07 & -0.01 & 0.04 & 0.22 & -0.01 & 0.07 \\
\hline \multicolumn{11}{|c|}{ Control Variables: } \\
\hline$L E V$ & 0.83 & 1.49 & 29.31 & 0.84 & 2.15 & 1.28 & $1.13 *$ & 6.91 & 0.49 & 2.05 \\
\hline GROWTH & 0.10 & 0.08 & 0.25 & -0.03 & 0.19 & 0.10 & 0.07 & 0.20 & -0.01 & 0.17 \\
\hline EQUITY_ISS & 0.14 & 0.00 & 1.00 & -0.06 & 0.11 & 0.10 & 0.00 & 0.40 & 0.00 & 0.04 \\
\hline$A S S E \bar{T} \_T U R N$ & 0.80 & 0.77 & 0.45 & 0.47 & 1.02 & $1.13 *$ & $1.03 *$ & 0.77 & 0.54 & 1.52 \\
\hline SIZE & 8.39 & 8.69 & 1.97 & 0.84 & 9.73 & $5.88 *$ & $5.93 *$ & 2.35 & 4.04 & 7.50 \\
\hline$C F$ & 0.00 & 0.00 & 0.07 & -0.01 & 0.02 & 0.01 & 0.00 & 0.13 & -0.01 & 0.02 \\
\hline
\end{tabular}

$*, * * * * *$ Significantly different between cross-listed and US firms at the $0.01,0.05$, and 0.10 levels respectively (two-tailed).

${ }^{a}$ We define $C H A N G E N I$ as the change in annual net income, where net income is scaled by end-of-year total assets; $C H A N G E C F$ as the change in annual net cash flow, where cash flow is scaled by end-of-year total assets; TOTACC as net income less cash flow from operating activities, scaled by end-of-year total assets; $C F$ as annual net cash flow from operating

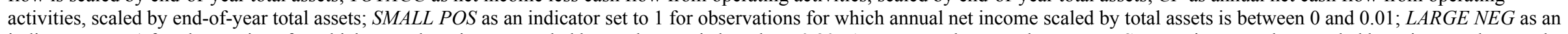

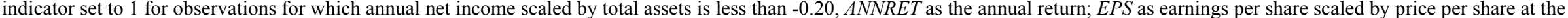

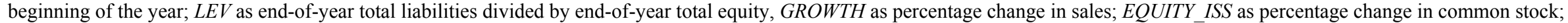
$D E B T$ ISS as the percentage change in total liabilities during the period; ASSET_TURN as sales divided by end-of-year total assets; SIZE as the natural log of market value of equity in millions as of the end of the year. 


\section{Panel B: Correlation Matrix}

Spearman (Pearson) above (below) the diagonal

\begin{tabular}{|c|c|c|c|c|c|c|c|c|c|c|c|c|c|c|}
\hline & ANNRET & ASSTTURN & $\begin{array}{c}\text { SMALL } \\
\text { POS }\end{array}$ & $\begin{array}{l}\text { LARGE } \\
\text { NEG }\end{array}$ & GROWTH & TOTACC & DEBTISS & EQISS & $E P S$ & $L E V$ & SIZE & $C F$ & $\begin{array}{c}C H A N G E_{-} \\
N I\end{array}$ & $\begin{array}{c}C H A N G E- \\
C F\end{array}$ \\
\hline ANNRET & 1.00 & -0.01 & -0.01 & $-0.12 *$ & $0.21 *$ & $0.13 *$ & $0.07 *$ & 0.16 * & $0.28 *$ & 0.02 & $0.25 *$ & 0.19 * & $0.28 *$ & $0.09 *$ \\
\hline ASSTTURN & $-0.04 * *$ & 1.00 & 0.00 & $-0.05 * *$ & -0.04 & $0.14 *$ & $-0.14 *$ & $-0.08 *$ & $0.13 *$ & $0.10 *$ & $-0.12 *$ & -0.01 & 0.03 & -0.01 \\
\hline SMALL POS & -0.03 & 0.00 & 1.00 & $-0.06 * *$ & $-0.07 *$ & $-0.14 *$ & -0.03 & 0.03 & $-0.17 *$ & $0.11 *$ & 0.04 & -0.03 & -0.04 & 0.01 \\
\hline$L A R G E N E G$ & $-0.05 * *$ & -0.02 & $-0.06 * *$ & 1.00 & $-0.07 *$ & $-0.29 *$ & -0.01 & $0.07 *$ & $-0.33 *$ & $-0.15 *$ & $-0.23 *$ & $-0.11 *$ & $-0.23 *$ & $-0.05 * *$ \\
\hline GROWTH & $0.18 *$ & $-0.05 * *$ & $-0.05 * *$ & -0.04 & 1.00 & $0.10 *$ & $0.41 *$ & $0.31 *$ & $0.11 *$ & $-0.06 *$ & $0.07 *$ & 0.10 * & $0.14 *$ & $0.06 * *$ \\
\hline TOTACC & -0.04 & $0.09 *$ & -0.01 & $-0.59 *$ & 0.02 & 1.00 & -0.03 & $-0.12 *$ & $0.56 *$ & $-0.11 *$ & $0.24 *$ & $-0.40 *$ & 0.30 * & $-0.32 *$ \\
\hline DEBTISS & $0.11 *$ & $-0.08 *$ & -0.02 & 0.00 & $0.09 *$ & $-0.20 *$ & 1.00 & $0.20 *$ & -0.02 & 0.01 & 0.03 & $0.08 *$ & $-0.18 *$ & 0.02 \\
\hline EQISS & $0.15 *$ & $-0.06 * *$ & -0.02 & -0.01 & $0.15 *$ & $-0.06 * *$ & $0.15 *$ & 1.00 & $-0.13 *$ & $-0.08 *$ & $-0.05 * *$ & $0.08 *$ & -0.01 & $0.05 * *$ \\
\hline$E P S$ & $0.11 *$ & 0.04 & 0.00 & $-0.40 *$ & $0.09 *$ & $0.45 *$ & -0.04 & 0.00 & 1.00 & $0.05 * *$ & $0.12 *$ & $0.11 *$ & $0.44 *$ & $0.06 * *$ \\
\hline$L E V$ & $0.01 *$ & -0.01 & 0.02 & -0.02 & -0.01 & 0.01 & 0.00 & 0.00 & 0.01 & 1.00 & $0.23 *$ & -0.02 & 0.02 & -0.04 \\
\hline SIZE & $0.10 *$ & $-0.19 *$ & 0.04 & $-0.24 *$ & $0.10 *$ & $0.25 *$ & -0.02 & $0.05 * *$ & $0.19 *$ & 0.01 & 1.00 & 0.04 & $0.12 *$ & -0.04 \\
\hline$C F$ & $0.21 *$ & $-0.05 * *$ & -0.01 & $-0.21 *$ & $0.06 * *$ & $-0.32 *$ & $0.30 *$ & $0.12 *$ & $0.10 *$ & 0.01 & 0.02 & 1.00 & $0.12 *$ & $0.68 * *$ \\
\hline CHANGE_NI & $0.20 *$ & -0.03 & -0.01 & $-0.42 *$ & $0.05 * *$ & $0.37 *$ & -0.03 & 0.00 & $0.38 *$ & 0.02 & $0.07 *$ & 0.34 * & 1.00 & $0.09 *$ \\
\hline CHANGE_CF & $0.12 *$ & $-0.04 * *$ & 0.01 & $-0.11 *$ & 0.01 & $-0.34 *$ & $0.17 *$ & $0.06 * *$ & $0.07 *$ & 0.00 & -0.01 & $0.84 *$ & $0.33 *$ & 1.00 \\
\hline
\end{tabular}

*, ** Significantly different from zero at the 0.01 and 0.05 levels respectively (two-tailed).

All variables are defined in panel A. 
TABLE 3

Accounting Quality Analysis of Cross-Listed Firms vs. Growth-Matched US Firms $N=698$

\section{Panel A: Earnings Smoothing ${ }^{\mathrm{a}}$}

\begin{tabular}{lcc} 
Measure & Cross Listers & US Firms \\
\hline Variability of $\triangle N I$ & 0.005 & $0.011^{*}$ \\
Variability of $\triangle N I$ over $\triangle C F$ & 1.424 & 2.334 \\
Correlation of $A C C$ and $C F$ & -0.539 & $-0.305^{*}$
\end{tabular}

Panel B: Managing Towards Earnings Targets ${ }^{\mathrm{a}}$

\begin{tabular}{lc} 
Measure & Cross Listers \\
\hline Small Positive NI & $0.109^{\# \#}$
\end{tabular}

Panel C: Timely Loss Recognition

\begin{tabular}{|c|c|c|}
\hline Measure & Cross Listers & US Firms \\
\hline Large Negative $N I^{\mathrm{a}}$ & \multicolumn{2}{|c|}{$-0.117^{\# \#}$} \\
\hline Skewness of $E P S^{\mathrm{b}}$ & $0.762^{\#}$ & $-3.095^{\#}$ \\
\hline Basu Regression $R^{*} D U M$ Coefficient $^{\mathrm{c}}$ & $0.160^{\#}$ & $0.324 * *$ \\
\hline
\end{tabular}

Panel D: Association of Stock Prices and Returns with Accounting Data

\begin{tabular}{lcl} 
Regression $R^{2 \mathrm{~d}}$ & Cross Listers & US Firms \\
\hline Price & 0.021 & $0.251^{*}$ \\
Basu Good News & 0.001 & 0.004 \\
Basu Bad News & 0.025 & $0.099 *$
\end{tabular}

*, ** Significantly different between cross-listed and US firms at the 0.01 and 0.05 levels respectively (one-tailed).

\#, \#\# Significantly different from zero at the 0.01 and 0.05 levels respectively (two-tailed).

${ }^{a}$ We base the analysis on regressions including controls as defined in table 2, panel A as well as country fixed effects. We define variability of $\triangle N I(\triangle C F)$ as the variance of the residuals from a pooled regression of the changes in annual net income (net cash flows) scaled by total assets on the control variables. The variability of $\triangle N I$ over $\triangle C F$ is defined as the ratio of the variability of $\triangle N I$ divided by the variability of $\triangle C F$. The residuals are winsorized at the $1 \%$ level to control for outliers. Correlation of $A C C$ and $C F$ is the partial Spearman correlation between the residuals of accruals and the residuals of net cash flow; we compute both sets of residuals from a regression of each variable (scaled by total assets) on the control variables. The residuals are winsorized at the $1 \%$ level to control for outliers. For the percentage of small positive (large negative) $N I$, we estimate a separate regression model for each measure regressing an indicator variable set to 1 for cross-listing and 0 for US firms on a small positive (large negative) $N I$ variable and the control variables. The small positive (large negative) $N I$ variable is an indicator set to 1 for observations for which annual net income scaled by total assets is between 0 and 0.01 (less than -0.20 ) and set to 0 otherwise; the coefficient on the indicator variable is reported.

${ }^{\mathrm{b}} E P S$ is annual earnings per share deflated by price at beginning of the period. We obtain the significance test from Sheskin (2000).

${ }^{c}$ The regression is $E P S=\alpha+\beta_{1} R+\beta_{2} D U M+\beta_{3} R^{*} D U M+\varepsilon$ where EPS is annual earnings per share deflated by price at the beginning of the period, $R$ is the annual return, and $D U M$ is 1 if the return is negative and 0 otherwise. Country fixed effects are included in the model. We winsorize the continuous variables at the $1 \%$ level to control for outliers.

d The price regression is $P=\alpha+\beta_{1} B V P S+\beta_{2} N I P S+\varepsilon$ where $P$ is price as of six months after the fiscal year-end, $B V P S$ is book value of shareholders' equity per share, and NIPS is net income per share. All variables are scaled by price as of six months after the preceding year-end. The Basu good/bad news regression is $E P S=\alpha+\beta R+\varepsilon$, where $E P S$ is annual earnings per share deflated by price at the beginning of the period and $R$ is the annual return. Good news observations are those for which $R$ is nonnegative. Bad news observations are those for which $R$ is negative. In the case of the cross listing sample, we first regress the dependent variable on the fixed effect indicator variables. The residuals from these regressions are then used in the second stage model to determine an incremental $R^{2}$. We winsorize the continuous variables at the $1 \%$ level to control for outliers. We obtain significance tests of $R^{2}$ differences from Cramer (1987). 


\section{Panel E: Coefficient Estimates}

Earnings Smoothing

\begin{tabular}{|c|c|c|c|c|c|c|c|c|}
\hline Dependent Variable & \multicolumn{7}{|c|}{ Independent Variables } & \multirow{2}{*}{$\begin{array}{l}\text { Number of Significant } \\
\text { Fixed Effects }\end{array}$} \\
\hline & Size & Growth & Equity Issuance & Leverage & Debt Issuance & Asset Turnover & Profitability & \\
\hline$\Delta N I$ & $-0.013 *$ & 0.004 & 0.005 & 0.000 & $0.003 *$ & $-0.008 * * *$ & $-0.326^{*}$ & $3 / 33$ \\
\hline$\triangle C F$ & $-0.012 *$ & $0.046 *$ & 0.006 & 0.000 & $0.012 *$ & $-0.012 * *$ & $-0.402 *$ & $3 / 33$ \\
\hline$A C C$ & $0.018 *$ & 0.019 & $-0.010 * * *$ & 0.000 & $-0.011 *$ & $0.036 *$ & $\mathrm{n} / \mathrm{a}$ & $3 / 33$ \\
\hline$C F$ & 0.001 & 0.009 & $0.009 *$ & 0.000 & $0.011 *$ & -0.003 & $\mathrm{n} / \mathrm{a}$ & $2 / 33$ \\
\hline
\end{tabular}

Managing Towards Earnings Targets

Dependent Variable

Independent Variables

Number of

\begin{tabular}{|c|c|c|c|c|c|c|c|c|c|}
\hline \multirow[t]{2}{*}{ Dependent Variable } & \multicolumn{8}{|c|}{ Independent Variables } & Number of \\
\hline & Size & Growth & Equity Issuance & Leverage & Debt Issuance & $\begin{array}{c}\text { Asset } \\
\text { Turnover }\end{array}$ & Profitability & $\begin{array}{l}\text { Small Positive } \\
\text { NI Indicator }\end{array}$ & $\begin{array}{l}\text { Significant } \\
\text { Fixed Effects }\end{array}$ \\
\hline 0 for $U S, 1$ for $C L$ & $0.101 *$ & $-0.094 * * *$ & 0.001 & -0.000 & $-0.010 * *$ & $-0.132 *$ & -0.091 & $0.109 * *$ & $0 / 33$ \\
\hline
\end{tabular}

Timely Loss Recognition

\begin{tabular}{lccccc} 
Dependent Variable & Growth & $\begin{array}{c}\text { Equity } \\
\text { Issuance }\end{array}$ & Leverage & Debt Issuance \\
& Size & Independent Variables & \\
\hline 0 for US, 1 for CL & $0.099 *$ & $-0.099 * * *$ & 0.002 & -0.000 & $-0.010 * *$ \\
Dependent Variable & Sample & \multicolumn{3}{c}{ Independent Variables } & Number of Significant \\
\hline & CL & $R$ & DUM & $R^{*}$ Dum & Fixed Effects \\
$E P S$ & US & -0.009 & -0.002 & $0.160 *$ & $0 / 33$ \\
$E P S$ & & 0.001 & $0.324 *$ & $\mathrm{n} / \mathrm{a}$
\end{tabular}

Association of Stock Prices and Returns with Accounting Data

\begin{tabular}{llcccc} 
Dependent Variable & Sample & \multicolumn{3}{c}{ Independent Variables } & Number of Significant \\
\cline { 1 - 4 } & & $R$ & $N I P S$ & $B V P S$ & Fixed Effects \\
Price & CL & & $0.266^{* * *}$ & $0.076^{*}$ & $0 / 33$ \\
Price & US & & $0.274^{* *}$ & $0.548^{*}$ & $\mathrm{n} / \mathrm{a}$ \\
$E P S$ (good news) & CL & 0.005 & & & $0 / 29$ \\
$E P S$ (good news) & US & -0.011 & & & $\mathrm{n} / \mathrm{a}$ \\
$E P S$ (bad news) & CL & $0.086^{*}$ & & & $2 / 30$ \\
$E P S$ (bad news) & US & $0.309^{*}$ & & & $\mathrm{n} / \mathrm{a}$
\end{tabular}

*, ** Significantly different from zero at the 0.01 and 0.05 levels respectively (two-tailed). 
TABLE 4

Accounting Quality Analysis of Cross-Listed Firms vs. Size-Matched US Firms

$N=698$

Panel A: Earnings Smoothing ${ }^{\mathrm{a}}$

\begin{tabular}{lcc} 
Measure & Cross Listers & US Firms \\
\hline Variability of $\triangle N I$ & 0.005 & $0.006^{*}$ \\
Variability of $\triangle N I$ over $\triangle C F$ & 1.512 & 2.168 \\
Correlation of $A C C$ and $C F$ & -0.514 & $-0.279^{*}$
\end{tabular}

Panel B: Managing Towards Earnings Targets ${ }^{\text {a }}$

\begin{tabular}{|c|c|c|}
\hline Measure & Cross Listers & US Firms \\
\hline Small Positive $N I$ & & \\
\hline
\end{tabular}

Panel C: Timely Loss Recognition

\begin{tabular}{|c|c|c|}
\hline Measure & Cross Listers & US Firms \\
\hline Large Negative $N I^{\text {a }}$ & \multicolumn{2}{|c|}{$-0.253^{\# \#}$} \\
\hline Skewness of $E P S^{\mathrm{b}}$ & $0.762^{\#}$ & $-3.053^{\#}$ \\
\hline Basu Regression $R^{*} D U M$ Coefficient $^{\mathrm{c}}$ & $0.160^{\#}$ & $0.253^{\#} * *$ \\
\hline
\end{tabular}

Panel D: Association of Stock Prices and Returns with Accounting Data

\begin{tabular}{lcl} 
Regression $R^{2 \mathrm{~d}}$ & Cross Listers & US Firms \\
\hline Price & 0.021 & 0.034 \\
Basu Good News & 0.001 & $0.126 *$ \\
Basu Bad News & 0.025 & $0.115 * *$
\end{tabular}

\footnotetext{
*, ** Significantly different between cross-listed and US firms at the 0.01 and 0.05 levels respectively (one-tailed). \#, \#\# Significantly different from zero at the 0.01 and 0.05 levels respectively (two-tailed).

${ }^{a}$ We base the analysis on regressions including controls as defined in table 2, panel A as well as country fixed effects. We define variability of $\triangle N I(\triangle C F)$ as the variance of the residuals from a pooled regression of the changes in annual net income (net cash flows) scaled by total assets on the control variables. The variability of $\triangle N I$ over $\triangle C F$ is defined as the ratio of the variability of $\triangle N I$ divided by the variability of $\triangle C F$. The residuals are winsorized at the $1 \%$ level to control for outliers. Correlation of $A C C$ and $C F$ is the partial Spearman correlation between the residuals of accruals and the residuals of net cash flow; we compute both sets of residuals from a regression of each variable (scaled by total assets) on the control variables. The residuals are winsorized at the $1 \%$ level to control for outliers. For the percentage of small positive (large negative) $N I$, we estimate a separate regression model for each measure regressing an indicator variable set to 1 for cross-listing and 0 for US firms on a small positive (large negative) $N I$ variable and the control variables. The small positive (large negative) $N I$ variable is an indicator set to 1 for observations for which annual net income scaled by total assets is between 0 and 0.01 (less than -0.20 ) and set to 0 otherwise; the coefficient on the indicator variable is reported.

${ }^{\mathrm{b}}$ EPS is annual earnings per share deflated by price at beginning of the period. We obtain the significance test from Sheskin (2000).

${ }^{\mathrm{c}}$ The regression is $E P S=\alpha+\beta_{1} R+\beta_{2} D U M+\beta_{3} R^{*} D U M+\varepsilon$ where EPS is annual earnings per share deflated by price at the beginning of the period, $R$ is the annual return, and $D U M$ is 1 if the return is negative and 0 otherwise. Country fixed effects are included in the model. We winsorize the continuous variables at the $1 \%$ level to control for outliers.

${ }^{\mathrm{d}}$ The price regression is $P=\alpha+\beta_{1} B V P S+\beta_{2} N I P S+\varepsilon$ where $P$ is price as of six months after the fiscal year-end, $B V P S$ is book value of shareholders' equity per share, and NIPS is net income per share. All variables are scaled by price as of six months after the preceding year-end. The Basu good/bad news regression is $E P S=\alpha+\beta R+\varepsilon$, where $E P S$ is annual earnings per share deflated by price at the beginning of the period and $R$ is the annual return. Good news observations are those for which $R$ is nonnegative. Bad news observations are those for which $R$ is negative. In the case of the cross listing sample, we first regress the dependent variable on the fixed effect indicator variables. The residuals from these regressions are then used in the second stage model to determine an incremental $R^{2}$. We winsorize the continuous variables at the $1 \%$ level to control for outliers. We obtain significance tests of $R^{2}$ differences from Cramer (1987).
} 
TABLE 5

Accounting Quality Analysis of Cross-Listed vs. US Firms

Growth Matched: Split on Investor Protection

Panel A: Earnings Smoothing ${ }^{\text {a }}$

\begin{tabular}{lcccc} 
& \multicolumn{2}{c}{ Low Protection $(\mathrm{N}=292)$} & \multicolumn{2}{c}{ High Protection $(\mathrm{N}=406)$} \\
\hline Measure & Cross Listers & US Firms & Cross Listers & US Firms \\
\hline Variability of $\triangle N I$ & 0.004 & $0.012 *$ & 0.005 & $0.011^{*}$ \\
Variability of $\triangle N I$ over $\triangle C F$ & 1.460 & 3.301 & 1.665 & 1.883 \\
Correlation of $A C C$ and $C F$ & -0.535 & $-0.216^{*}$ & -0.533 & $-0.304 *$
\end{tabular}

Panel B: Managing Towards Earnings Targets ${ }^{a}$

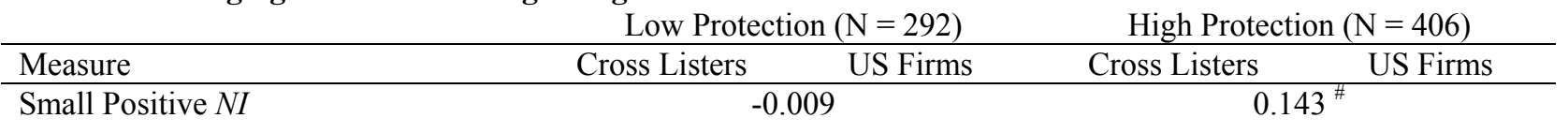

Panel C: Timely Loss Recognition

\begin{tabular}{|c|c|c|c|c|}
\hline & \multicolumn{2}{|c|}{ Low Protection $(N=292)$} & \multicolumn{2}{|c|}{ High Protection $(\mathrm{N}=406)$} \\
\hline Measure & Cross Listers & US Firms & Cross Listers & US Firms \\
\hline Large Negative $N I^{\text {a }}$ & -0.2 & & -0. & \\
\hline Skewness of $E P S^{\mathrm{b}}$ & 1.081 & $-3.035^{\#}$ & $-2.034^{\#}$ & $-2.997^{\ddagger}$ \\
\hline Basu Regression $R^{*} D U M$ Coefficient $^{\mathrm{c}}$ & 0.082 & 0.379 \#* & 0.247 \# & 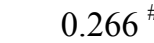 \\
\hline
\end{tabular}

Panel D: Association of Stock Prices and Returns with Accounting Data

\begin{tabular}{lcccc} 
& \multicolumn{2}{c}{ Low Protection $(\mathrm{N}=292)$} & \multicolumn{2}{c}{ High Protection $(\mathrm{N}=406)$} \\
\hline Regression $R^{2 \mathrm{~d}}$ & Cross Listers & US Firms & Cross Listers & US Firms \\
\hline Price & 0.021 & $0.219^{*}$ & 0.025 & $0.272^{*}$ \\
Basu Good News & 0.004 & 0.001 & 0.002 & 0.003 \\
Basu Bad News & 0.002 & $0.147^{*}$ & 0.170 & 0.047 \\
\hline
\end{tabular}

*, ** Significantly different between cross-listed and US firms at the 0.01 and 0.05 levels respectively (one-tailed).

\#, \#\# Significantly different from zero at the 0.01 and 0.05 levels respectively (two-tailed).

${ }^{\mathrm{a}} \mathrm{We}$ base the analysis on regressions including controls as defined in table 2, panel A as well as country fixed effects. We define variability of $\triangle N I(\triangle C F)$ as the variance of the residuals from a pooled regression of the changes in annual net income (net cash flows) scaled by total assets on the control variables. The variability of $\triangle N I$ over $\triangle C F$ is defined as the ratio of the variability of $\triangle N I$ divided by the variability of $\triangle C F$. The residuals are winsorized at the $1 \%$ level to control for outliers. Correlation of $A C C$ and $C F$ is the partial Spearman correlation between the residuals of accruals and the residuals of net cash flow; we compute both sets of residuals from a regression of each variable (scaled by total assets) on the control variables. The residuals are winsorized at the $1 \%$ level to control for outliers. For the percentage of small positive (large negative) NI, we estimate a separate regression model for each measure regressing an indicator variable set to 1 for cross-listing and 0 for US firms on a small positive (large negative) $N I$ variable and the control variables. The small positive (large negative) $N I$ variable is an indicator set to 1 for observations for which annual net income scaled by total assets is between 0 and 0.01 (less than -0.20 ) and set to 0 otherwise; the coefficient on the indicator variable is reported.

${ }^{\mathrm{b}}$ EPS is annual earnings per share deflated by price at beginning of the period. We obtain the significance test from Sheskin (2000).

${ }^{c}$ The regression is EPS $=\alpha+\beta_{1} R+\beta_{2} D U M+\beta_{3} R^{*} D U M+\varepsilon$ where EPS is annual earnings per share deflated by price at the beginning of the period, $R$ is the annual return, and $D U M$ is 1 if the return is negative and 0 otherwise. Country fixed effects are included in the model. We winsorize the continuous variables at the $1 \%$ level to control for outliers.

d The price regression is $P=\alpha+\beta_{1} B V P S+\beta_{2} N I P S+\varepsilon$ where $P$ is price as of six months after the fiscal year-end, $B V P S$ is book value of shareholders' equity per share, and NIPS is net income per share. All variables are scaled by price as of six months after the preceding year-end. The Basu good/bad news regression is $E P S=\alpha+\beta R+\varepsilon$, where $E P S$ is annual earnings per share deflated by price at the beginning of the period and $R$ is the annual return. Good news observations are those for which $R$ is nonnegative. Bad news observations are those for which $R$ is negative. In the case of the cross listing sample, we first regress the dependent variable on the fixed effect indicator variables. The residuals from these regressions are then used in the second stage model to determine an incremental $R^{2}$. We winsorize the continuous variables at the $1 \%$ level to control for outliers. We obtain significance tests of $R^{2}$ differences from Cramer (1987). 
TABLE 6

Accounting Quality Analysis of Cross-Listed vs. US Firms

Growth Matched: Split on US GAAP in home accounts

Panel A: Earnings Smoothing ${ }^{\text {a }}$

\begin{tabular}{lcccc} 
& \multicolumn{2}{c}{ Not Using US GAAP (N=498) } & \multicolumn{2}{c}{ Using US GAAP (N=200) } \\
\hline Measure & Cross Listers & US Firms & Cross Listers & US Firms \\
\hline Variability of $\triangle N I$ & 0.004 & $0.011^{*}$ & 0.006 & $0.013^{*}$ \\
Variability of $\triangle N I$ over $\triangle C F$ & 1.415 & 2.672 & 1.947 & 2.031 \\
Correlation of $A C C$ and $C F$ & -0.572 & $-0.262 *$ & -0.477 & -0.387
\end{tabular}

Panel B: Managing Towards Earnings Targets ${ }^{\text {a }}$

\begin{tabular}{lcccc} 
& \multicolumn{2}{c}{ Not Using US GAAP (N=498) } & \multicolumn{2}{c}{ Using US GAAP (N=200) } \\
\hline Measure & Cross Listers & US Firms & Cross Listers & US Firms \\
\hline Small Positive $N I$ & & 0.085 & \multicolumn{2}{c}{$0.140^{\# \#}$}
\end{tabular}

Panel C: Timely Loss Recognition

\begin{tabular}{|c|c|c|c|c|}
\hline & \multicolumn{2}{|c|}{ Not Using US GAAP $(\mathrm{N}=498)$} & \multicolumn{2}{|c|}{ Using US GAAP $(\mathrm{N}=200)$} \\
\hline Measure & Cross Listers & US Firms & Cross Listers & US Firms \\
\hline Large Negative $N I^{\text {a }}$ & \multicolumn{2}{|c|}{$-0.214^{\#}$} & \multicolumn{2}{|c|}{0.067} \\
\hline Skewness of $E P S^{\mathrm{b}}$ & $0.913^{\#}$ & $-2.907^{\#}$ & $-1.300^{\#}$ & $-3.246^{\#}$ \\
\hline Basu Regression $R * D U M$ Coefficient $^{\mathrm{c}}$ & $0.163^{\#}$ & $0.355^{\# * * *}$ & $0.093^{\#}$ & $0.234^{\# * *}$ \\
\hline \multicolumn{5}{|c|}{ Panel D: Association of Stock Prices and Returns with Accounting Data } \\
\hline & \multicolumn{2}{|c|}{ Not Using US GAAP $(\mathrm{N}=498)$} & \multicolumn{2}{|c|}{ Using US GAAP $(\mathrm{N}=200)$} \\
\hline Regression $R^{2 \mathrm{~d}}$ & Cross Listers & US Firms & Cross Listers & US Firms \\
\hline Price & 0.022 & $0.209 *$ & 0.005 & $0.375 *$ \\
\hline Basu Good News & 0.005 & 0.006 & 0.000 & 0.000 \\
\hline Basu Bad News & 0.011 & $0.111 *$ & 0.024 & 0.055 \\
\hline
\end{tabular}

* ** Significantly different between cross-listed and US firms at the 0.01 and 0.05 levels respectively (one-tailed).

\#, \#\# Significantly different from zero at the 0.01 and 0.05 levels respectively (two-tailed).

${ }^{\mathrm{a}}$ We base the analysis on regressions including controls as defined in table 2, panel A as well as country fixed effects. We define variability of $\triangle N I(\triangle C F)$ as the variance of the residuals from a pooled regression of the changes in annual net income (net cash flows) scaled by total assets on the control variables. The variability of $\triangle N I$ over $\triangle C F$ is defined as the ratio of the variability of $\triangle N I$ divided by the variability of $\triangle C F$. The residuals are winsorized at the $1 \%$ level to control for outliers. Correlation of $A C C$ and $C F$ is the partial Spearman correlation between the residuals of accruals and the residuals of net cash flow; we compute both sets of residuals from a regression of each variable (scaled by total assets) on the control variables. The residuals are winsorized at the $1 \%$ level to control for outliers. For the percentage of small positive (large negative) $N I$, we estimate a separate regression model for each measure regressing an indicator variable set to 1 for cross-listing and 0 for US firms on a small positive (large negative) $N I$ variable and the control variables. The small positive (large negative) $N I$ variable is an indicator set to 1 for observations for which annual net income scaled by total assets is between 0 and 0.01 (less than -0.20 ) and set to 0 otherwise; the coefficient on the indicator variable is reported.

${ }^{\mathrm{b}}$ EPS is annual earnings per share deflated by price at beginning of the period. We obtain the significance test from Sheskin (2000).

${ }^{c}$ The regression is $E P S=\alpha+\beta_{1} R+\beta_{2} D U M+\beta_{3} R^{*} D U M+\varepsilon$ where EPS is annual earnings per share deflated by price at the beginning of the period, $R$ is the annual return, and $D U M$ is 1 if the return is negative and 0 otherwise. Country fixed effects are included in the model. We winsorize the continuous variables at the $1 \%$ level to control for outliers.

d The price regression is $P=\alpha+\beta_{1} B V P S+\beta_{2} N I P S+\varepsilon$ where $P$ is price as of six months after the fiscal year-end, $B V P S$ is book value of shareholders' equity per share, and NIPS is net income per share. All variables are scaled by price as of six months after the preceding year-end. The Basu good/bad news regression is $E P S=\alpha+\beta R+\varepsilon$, where $E P S$ is annual earnings per share deflated by price at the beginning of the period and $R$ is the annual return. Good news observations are those for which $R$ is nonnegative. Bad news observations are those for which $R$ is negative. In the case of the cross listing sample, we first regress the dependent variable on the fixed effect indicator variables. The residuals from these regressions are then used in the second stage model to determine an incremental $R^{2}$. We winsorize the continuous variables at the $1 \%$ level to control for outliers. We obtain significance tests of $R^{2}$ differences from Cramer (1987). 